\title{
Pengorganisasian Dana Ziswaf Pada Program Ekonomi Masyarakat Mandiri
}

\author{
Erik Saepudin $^{1 *}$, Dewi Sadiah $1^{1}$, Ali Azis $2^{2}$ \\ ${ }^{12}$ Jurusan Manajemen Dakwah, Fakultas Dakwah dan Komunikasi, UIN Sunan Gunung Djati, \\ Bandung \\ ${ }^{2}$ Jurusan Pengembangan Masyarakat Islam, Fakultas Dakwah dan Komunikasi, UIN Sunan \\ Gunung Djati, Bandung \\ *Email : erik.saepudinfidkom5@gmail.com
}

\begin{abstract}
ABSTRAK
Tujuan penelitian ini adalah (1) Untuk mengetahui struktur organisasi pada program ekonomi masyarakat mandiri; (2) Untuk mengetahui kompetensi sumber daya pada program ekonomi masyarakat mandiri; (3) Untuk mengetahui hasil dari pengorganisasian dana ziswaf pada program ekonomi masyarakat mandiri. Metode yang digunakan dalam penelitian ini adalah studi kasus dengan pendekatan kuallitatif, sumber data yang digunakan adalah data primer dan sekunder, adapun teknik pengumpulan data yang digunakan adalah observasi, wawancara,dan studi dokumentasi. Hasil penelitian ini menunjukan bahwa : Pertama struktur organisasi yang diterapkan dikelompok kampung ternak Al Ikhwan Cianjur adalah pengorganisasian garis, dalam model ini kekuasaan pendamping langsung kepada ketua kelompok yang merupakan, kemudian ke anggota dan mitra. Adapun struktur organisasi ini sederhana; Kedua kompetensi sumberdaya sudah sesuai dengan harapan dari mulai sumber daya manusia dan non manusia karena terlebih dahulu dilakukan observasi; Ketiga adanya stuktural secara tertulis, tupoksi masing-masing anggota berjalan, alur komando jelas, dan peningkatan sumber daya pun diselenggarakan serta program ini meningkatkan perekonomian warga atau penerima manfaatan sebesar Rp. 700.000/orang.
\end{abstract}

Kata Kunci: Pengorganisasian; Dana Ziswaf; Ekonomi Masyarakat Mandiri.

\section{ABSTRACT}

The purpose of this study are (1) to find out the organizational structure in an independent community economic program; (2) To know the competence of resources in an independent community economic program; (3) To find out the results of organizing zisafaf funds in an independent community economic program. The method used in this study is a case study with a qualitative approach, the data sources used are primary and secondary data, while the data 
E. Saepudin, D. Sadiah, A. Aziz

collection techniques used are observation, interviews, and documentation studies. The results of this study indicate that: First the organizational structure applied in the Al Ikhwan Cianjur livestock village group is organizing lines, in this model the power of the companion directly to the group leader who is, then to the members and partners. The organizational structure is simple; Both resource competencies are in line with expectations from starting buman and nonbuman resources because observation is first done; Third, there is a written structure, the duties and functions of each member are running, the flow of command is clear, and the improvement of resources is carried out and this program improves the economy of the citizens or beneficiaries of Rp. 700,000 / person.

Keywords: Organizing; Dana Ziswaf; Independent Community Economy.

\section{PENDAHULUAN}

Berdasarkan hasil pnelusuran dari wawancara dengan Apri sebagai manajer program menyatakan bahwa Dompet Dhuafa merupakan salah satu lembaga Nirlaba milik masyarakat Indonesia yang berhidmat mengangkat sosial kemanusian kaum Dhuafa dengan dana ZISWAF ( Zakat, Infak, Sodaqah dan Wakaf ), yang diperoleh dari perorangan, kelompok, dan perusahaan/lembaga. Kelahirannya berawal dari empat kolektif komunitas jurnalis yang banyak berinteraksi dengan masyarakat miskin, sekaligus bertemu dengan orang kaya. Digagaslah manajemen galang kebersamaan dengan siapapun yang berkepedulian kepada kaum dhuafa. Sesuai dengan ketentuan hukum yang berlaku, dompet dhuafa tercatat di departemen sosial RI sebagai organisasi yang berbentuk yayasan. pembentukan yayasan dilakukan di hadapan Notaris H. Abu Yusuf, SH tanggal 14 September 1994 diumumkan dalam berita Negara RI No. 163/A.YAY.HKM/1996/PENJAKSEL (Wawancara 8 April 2018).

Peran dari lembaga Amil Zakat Dompet Dhuafa adalah untuk membantu Badan Amil Zakat dalam mengelola dan mendistribusikan zakat yang dikeluarkan oleh para muzaki yang kemudian bisa disampaikan kepada yang haknya.

Jejaring-jejaring Dompet Dhuafa diantaranya pertama Jejaring Pengelolaan Zakat (JPZ) yang melaksanakan pengelolaan baik yang dibentuk masyarakat inginpun yang dibentuk oleh pihak dompet dhuafa secara langsung, kedua Jejaring Asset Sosial (JAS) yang berfungsi sebagai pemberdayaan dompet dhuafa di bidang karitas dan pengembangan insane serta menangani program/ bentuk ahir dari program pemberdayaan, ketiga Jejaring Asset Reform (JAR) salah satu yang melaksanakan fungsi pemberdayaan dompet dhuafa di bidang pengembangan Ekonomi (Zen, 2005: 125).

Kehadiran Dompet Dhuafa ini memberikan suatu warna baru dalam dunia Islam khususnya mengenai pendistribusian zakat. Inovasi demi inovasi yang dilakukan dompet dhuafa mengenai pendistribusian dana Ziswaf, tidak hanya pada Zakat yang bersifat konsumtif saja, tetapi dompet dhuafa menyalurkan 
kepada hal yang berkelanjutan buat kedepannya. Karena harapannya zakat dapat menjadi solusi dari permaslahan yang ada, maka disalurkanlah dana Ziswaf yang bersifat produktif yang tujuan kedepannya supaya bisa menjadi muzaki karena adanya perguliran uang yang secara sistematis.

Penyaluran dana Ziswaf yang dilakukan oleh dompet dhuafa yang sifatnya produktif ini banyak lahir program program baik dibidang Kesehatan, ekonomi, sosial masyarakat, pendidikan dan kemanusiaan. Ekonomi Masyarakat Mandiri adalah salah satu program bagian pengembangan Ekonomi. yang dimaksudkan, memberikan kemandirian kepada masyarakat dalam hal perekonomian, khususnya dibagian perternakan seperti sapi, domba, dan kambing yang nantinya diperutukan untuk program tebar hewan qurban. tidak hanya sebatas memfasilitasi dalam hal materi, namun diberikan suatu pelatihan dan pemantauan yang berkelanjutan agar dapat memastikan bahwa program dijalankan sesuai dengan harapan.

Pengorganisasian menjadi sangat penting agar program-program yang dilakukan tidak salah sasaran atau gagal program, ada beberapa tahapan dalam pengorganisasian menurut Eddy Soeryanto dalam membantu organisasi harus memperhatikan hal-hal penting antara lain: Pertama, menetapkan aktivitas kerja secara rinci terhadap pekerjaan yang dibutuhkan untuk menerapkan rencana dalam mencapai tujuan; Kedua, mengelompokan pekerjaan, untuk menerapkan rencana dalam mencapai tujuan; Ketiga, menugaskan orang tertentu; Keempat mengkoordinasikan aktivitas kelompok atau individu; Kelima, dilakukan evaluasi atas proses pengorganisasian (Sugoto, 2009: 60).

Uraian di atas menarik untuk diteliti mengenai pengorganisaian aspekaspek program Pemberdayaan Ekonomi Masyarakat Mandiri yang diselenggarakan oleh Dompet Dhuafa, karena yang dikelola adalah dana umat. sehingga ini bisa menjadi solusi bagi permasalahan yang ada di sekitaran masyarakat.

Peneliltian ini berfokus pada Pengorganisasian Dana ZISWAF pada program Ekonomi Masyarakat Mandiri di Dompet Dhuafa atau lebih spesifikasinya di Kampung Ternak Desa Mekarmanik Kecamatan Cimenyan Kabupaten Bandung sebagai penerima manfaat dari program yang diadakan oleh Dompet Dhufa Jabar. Nantinya akan mengungkap bagaimana pola yang diterapkan oleh Dompet Dhuafa pada program tersebut, serta pembagian tugas dalam melaksanakan program tersebut.

Tujuan penelitian ini adalah: (1) Untuk mengetahui struktur organisasi pada program ekonomi masyarakat mandiri; (2) Untuk mengetahui kompetensi sumber daya pada program ekonomi masyarakat mandiri; (3) Untuk mengetahui hasil dari pengorganisasian dana ziswaf pada program ekonomi masyarakat mandiri. 
Hasil dari penelitian ini diharapkan dapat berguna untuk menambah dan memperluas khasanah pengetahuan dalam ilmu manajemen terutama mengenai pengorganisasia, serta temuan ini diharapkan bisa menjadi bahan kajian bagi jurusan Manajemen Dakwah untuk dijadikan suatu fokusan dalam perkuliahan. adapaun bagi yang lainnya bisa dijadikan suatu masukan yang positif bagi lembaga yang bersangkutan.

Manfaat dari penelitian ini dilihat dari segi teoritis diharapkan dapat memperluas khasanah pemikiran, pegetahuan, pemahaman dalam ilmu manajemen terutama ilmu tentang pengorganisasian, dan diharapkan dapat dijadikan sebagai salah satu bahan kajian tersendiri bagi manajemen dakwah mengenai pengorganisasian yang kemudian akan menjadi suatu fokusan tersendiri, dan dapat pula dijadikan rujukan oleh lembaga yang bersangkutan. Sedangkan dari segi praktis diharapkan dapat memberikan masukan positif bagi lembaga/instansi baik dalam proses pembagian tugas, pola atau struktur kerja dan lain sebagainya dengan memahami pengorganisasian sehingga apa yang dicita-citakan bisa tercapai.

Metode yang digunakan dalam penelitian ini adalah studi kasus dengan pendekatan kualitatif, sumber data yang digunakan adalah data primer dan sekunder, adapun teknik pengumpulan data yang digunakan adalah observasi, wawancara, dan studi dokumentasi.

\section{LANDASAN TEORITIS}

Teori yang akan dijadikan landasan dalam penelitian ini adalah teori pengorganisasian, teori kompetensi sumber daya manusia dan teori zakat. Pengorganisasian (Organizing) merupakan aktivitas proses, cara dan pembuatan dalam mengorganisasi, yang diatur dalam tugas pekerjaan, jenis, sifat, dan pola kesatuan kerja, siapa yang akan melakukannya, apa alatnya, bagaimana kondisi keuangannya, dan fasilitas lainnya (Nafarin, 2007: 8-9).

Pengorganisasian merupakan proses mengatur dan mengalokasikan tugastugas, pekerjaan, wewenang, peran-peran termasuk koordinasi hubunganhubungan antar bagian baik secara vertikal inginpun secara horizontal dalam suatu struktur organiasasi yang diperlukan untuk mencapai tujuan yang telah ditentukaan (Silalahi, 2011: 42).

Proses atau tahapan pengorganisasian pada hakekatnya meruPakan cara bagaimana pekerjaan diatur dan dialokasikan dalam unit-unit organisasi dan di antara para anggota organisasi dapat bekerja efektif dan sumber-sumber pendukung dapat dimanfaatkan secara efisien dan efektif daalam pencapaian tujuan organisasi (Silalahi, 1996: 156).

Dalam pengorganisasian sumber daya manusia, modal, bahan baku, dan teknologi harus dikoordinasikan secara efektif untuk mencapai sasaran tim. Oleh karena itu maka dalam membantu organisasi harus memperhatikan hal-hal 
penting antara lain; Pertama, yang harus dilakukan adalah menetapkan aktivitas kerja secara rinci terhadap pekerjaan yang dibutuhkan untuk menerapkan rencana dalam mencapai tujuan; Kedua, mengelompokan pekerjaan, ketiga menugaskan orang tertentu, keempat mengoordinasikan aktivitas kelompok atau individu, kelima dilakukan evaluasi atas proses pengorganisasian (Soegoto, 2009: 260).

Struktur yaitu pola-pola formal dari interaksi dan koordinasi yang dirancang untuk menghubungkan tuga-tugas dari individu dan kelompok dalam mencapai tujuan organisasional, sedangkan struktur organisasi adalah suatu susunan dan hubungan antara tiap bagian serta posisi yang ada pada suatu organisasi atau perusahaan dalam menjalankan kegiatan oprasional untuk mencapai tujuan yang di harapkan (Silalahi, 1996: 407).

Struktur organisasi adalah menetapkan bagaimana tugas akan dibagi, siapa melaporkan kepada siapa, dan mekanisme koordinasi yang formal serta pola koordinasi yang di ikuti (Robbins, 1994: 6).

Kompetensi adalah suatu kemampuan untuk melaksanakan atau melakukan suatu pekerjaan atau tugas yang dilandasi atas keterampilan dan pengetahuan serta didukung oleh sikap kerja yang dituntut oleh pekerjaan tersebut. Dengan demikian, kompetensi menunjukan keterampilan atau pengetahuan yang dicirikan oleh profesionalisme dalam suatu bidang tertentu sebagai sesuatu yang terpenting, sebagai unggulan bidang tersebut (Wibowo, 2013: 324).

Kompetensi merupakan karakteristik mendasar yang dimiliki seseorang yang berpengaruh langsung terhadap, atau dapat memprediksikan kinerja yang sangat baik. Dengan kata lain, kompetensi adalah apa yang oustanding performers lakukan lebih sering, pada lebih banyak situasi, dengan hasil yang lebih baik daripada apa yang dilakukan penilai kebijakan. Faktor lain yang harus diperhatikan adalah perilaku.

Malthis dan Jackson mengemukakan bahwa kompetensi adalah karakteristik-karakteristik dasar yang dapat dihubungkan dengan kinerja yang meningkat dari individu-individu atau tim (Malthis, 2006: 219).

Setiap individu seseorang terdapat beberapa karakteristik kompetensi dasar, yang terdiri atas berikut ini: Pertama, watak (traits), yaitu yang membuat seseorang mempunyai sikap perilaku atau bagaimanakah orang tersebut merespon sesuatu dengan cara tertentu, misalnya percaya diri (self-confidence), kontrol diri (self-control), ketabahan atau daya tahan (hardiness); Kedua, motif (motive), yaitu sesuatu yang diinginkan seseorang atau secara konsisten dipikirkan dan diinginkan yang mengakibatkan suatu tindakan atau dasar dari dalam yang bersangkutan untuk melakukan suatu tindakan; Ketiga, bawaan (self-concept), yaitu sikap dan nilai-nilai yang dimiliki seseorang; Keempat, pengetahuan (knowledge), 
yaitu informasi yang dimiliki seseorang pada bidang tertentu dan pada area tertentu; Kelima, keterampilan atau keahlian (skill), yaitu kemampuan untuk melaksanakan tugas tertentu, baik secara fisik inginpun mental (Moeheriono, 2014: 14).

Tiga hal pokok dalam kompetensi SDM adalah: Pertama, pengetahuan (Knowladge), meruPakan penguasaan ilmu dan teknologi yang dimiliki seseorang, dan diperoleh melalui proses pembelajaran serta pengalaman selama kehidupannya. Indikator pengetahuan dalam hal ini adalah, pengetahuan manajemen bisnis, pengetahuan produk atau jasa, pengetahuan tentang konsumen, promosi dan strategi pemasaran.

Kedua, keterampilan (Skill), adalah kapasitas khusus untuk memanipulasi suatu objek secara fisik. Indikator keterampilan meliputi keterampilan produksi, berkomunikasi, kerjasama dan organisasi, pengawasan, keuangan, administrasi dan akuntansi.

Ketiga, kemampuan (Ability), adalah kapasitas seorang individu untuk mengerjakan berbagai tugas dalam suatu pekerjaan. Indikator kemampuan meliputi kemampuan mengelola bisnis, mengambil keputusan, memimpin, mengendalikan, berinovasi, situasi dan perubahan lingkungan bisnis (Brahmayanti, 2016: 49).

Dalam pasal 1 ayat 2 UU No.23 tahun 2011 tentang pengelolaan zakat, zakat didefinisikan sebagai harta yang wajib dikeluarkan oleh seorang muslim atau badan usaha untuk diberikan kepada yang berhak menerimanya sesuai dengan syariat Islam. Zakat sebagai rukun islam meruPakan suatu kewajiban muslim yang mampu untuk membayarnya dan diperuntukan bagi mereka yang berhak menerimanya. Dengan pengelolaannya yang baik zakat meruPakan sumber dana yang potensial yang dimanfaatkan untuk memajukan kesejahtraan umum bagi seluruh masyarakat, dan zakat meruPakan salah satu cara untuk mewujudkan kesimbangan sosial didunia dengan cara tolong menolong yang kaya memberi bantuan ke yang miskin, yang kuat member pertolongan ke yang lemah (Sari, 2006: 3).

Menurut UU No. 41 tahun 2004 wakaf adalah perbuatan hukum wakif (pemberi wakaf) untuk memisahkan dan atau menyerahkan sebagian harta benda miliknya untuk dimanfaatkan selamanya untuk jangka waktu tertentu sesuai dengan kepentingan guna keperluan ibadah dan atau kesejahtraan umum. Pelaksanaan hukum wakap di Indonesia semula masih sangat sederhana, tidak disertai administrasi, cukup dilakukan ikrar (Pernyataan) secara lisan. pengurusan dan pemeliharaan tanah wakaf kemudian di serahkan kepada Nazhir (Wadjdi, 2007: 38).

Program merupakan pernyataan yang berisi kesimpulan dari beberapa harapan atau tujuan yang saling bergantung dan saling terkait, untuk mencapai suatu sasaran yang sama. Biasanya suatu program mencakup seluruh kegiatan 
yang berada di bawah unit administrasi yang sama, atau sasaran-sasaran yang saling bergantung dan saling melengkapi, yang semuanya harus dilaksanakan secara bersamaan atau berurutan (Muhaimin, 2009: 349).

Kata masyarakat berasal dari bahasa arab, yaitu "Syaraka" yang artinya ikut serta, berpartisipasi, atau "Musyaraka" yang artinya saling bergaul. Dalam bahasa inggris di Pakai istilah Society. Kata tersebut berasal dari bahasa latin "Socius", yang artinya kawan (Koentjaraningrat, 2000: 143).

Masyarakat dalam istilah society diterjemahkan sebagai suatu badan atau kumpulan manusia yang hidup bersama sebagai anggota masyarakat. Anggota masyarakat yang dianggap sebagai suatu golongan, terbagi dalam berbagai kelas menurut kedudukan dalam masyarakat itu (Shadely, 1993: 59-60).

Masyarakat dalam istilah society diterjemahkan sebagai suatu badan atau kumpulan manusia yang hidup bersama sebagai anggota masyarakat. Anggota masyarakat yang dianggap sebagai suatu golongan, terbagi dalam berbagai kelas menurut kedudukan dalam masyarakat itu (Shadely, 1993: 59-60).

\section{HASIL DAN PEMBAHASAN}

Penelitian ini dilakukan pada Lembaga Amil Zakat Nasional Dompet Dhuafa Jawa Barat. Sebagai Pemberi Manfaat dan Kampung Ternak di Kp. Pasirsireum Desa Cikondaang Kecamatan Cibeber Kabupaten Cianjur sebegai Penerima Manfaat.

Dompet Dhuafa merupakan salah satu Lembaga Amil Zakat yang mampu Mengelola dan menyalurkan dana Ziswaf untuk didayagunakan ke delapan asnaf dan kaum dhuafa. Bahkan banyak inovasi dalam pendistribusian dana Ziswaf yang dilakukan oleh Dompet Dhuafa, inovasi tersebut berupa sesuatu yang produktif baik di bidang kesehatan, ekonomi, sosial, pendidikan, kemanusian. Karena tujuannya untuk menjadikan mustahik menjadi muzaki.

Hasil penelitian ini menemukan tentang struktur organisasi Dompet Dhuafa dan kampung ternak; kompetensi sumber daya Dompet Dhuafa dan kampung ternak; hasil pengorganisasian Dompet Dhuafa dan kampung ternak. 
E. Saepudin, D. Sadiah, A. Aziz

\section{Struktur Organisasi Dompet Dhuafa Jawa Barat dan Kampung Ternak Al Ikhwan Cianjur}

Gambar 3. Struktur Organisasi Dompet Dhuafa Jawa Barat

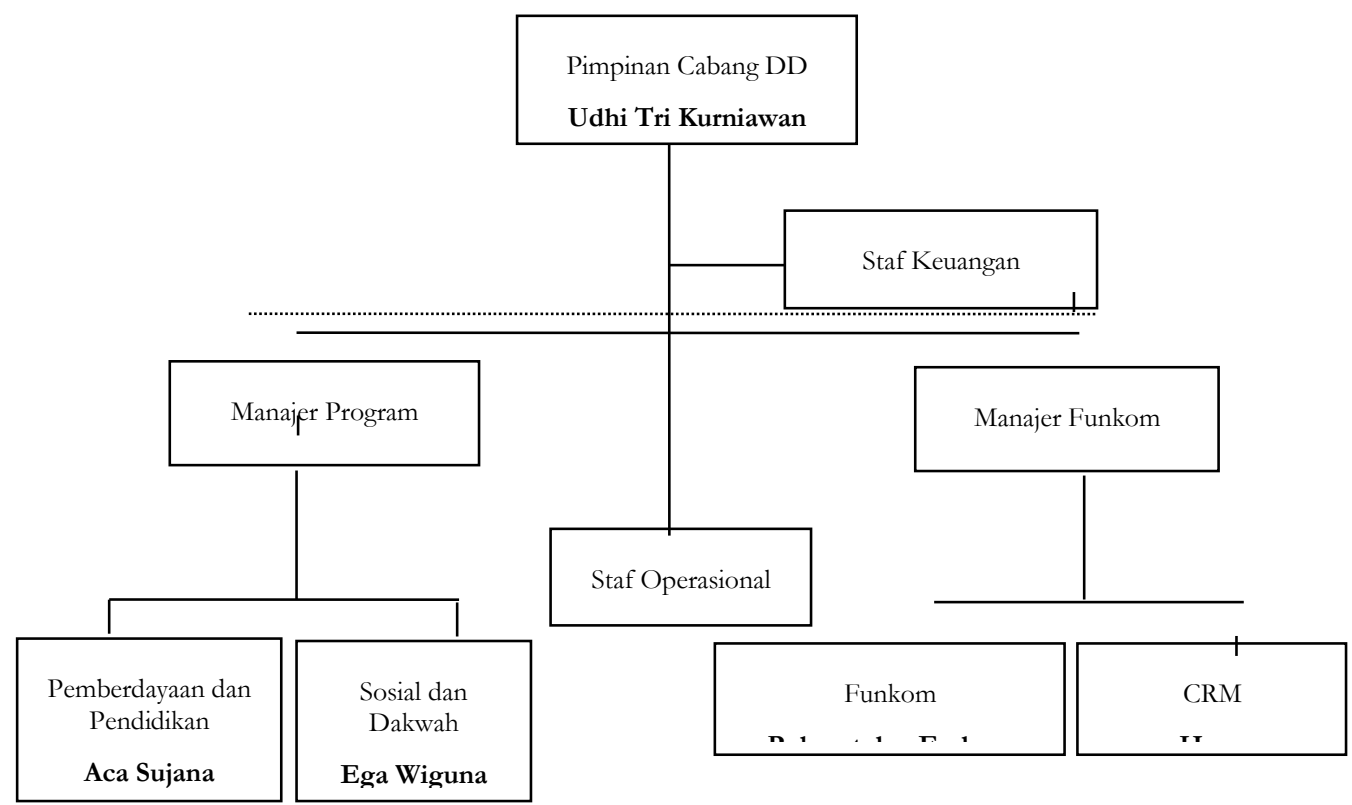

Sumber: Wawancara dengan manajer Program Sri Apriyanti 8 April 2018

Gambar 2. Struktur Organisasi Kampung Ternak Al Ikhwan Cianjur

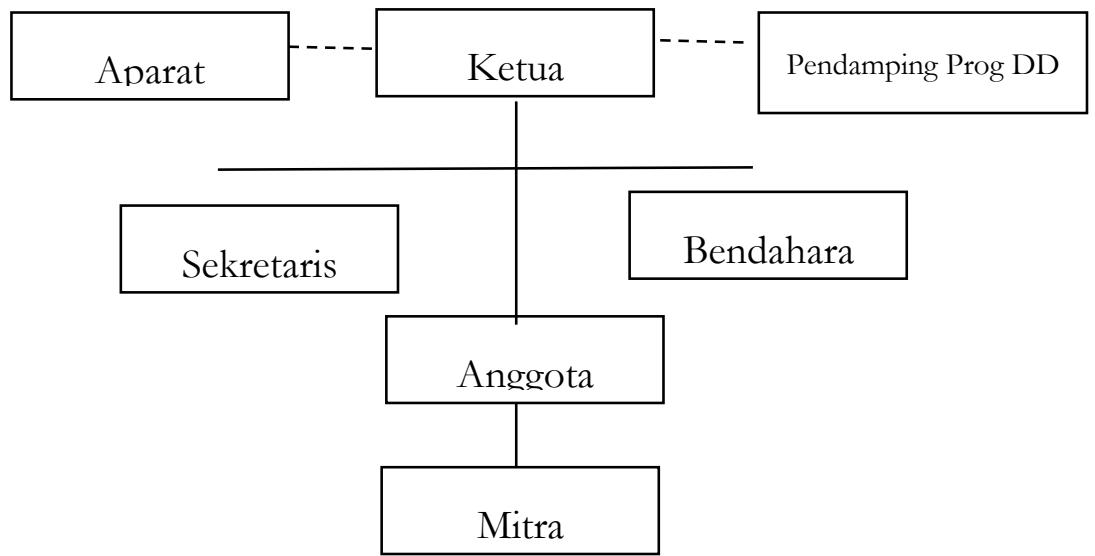

Sumber: Wawancara dengan Pendamping Program Kampung Ternak Al Ikhwan 08 April 2018 
Data Penerima Manfaa Kampung Ternak Al Ikhwan Cianjur

Tabel 1. Data Penerima Manfaat Kampung Ternak Al Ikhwan Cianjur

\begin{tabular}{lll}
\hline Anggota & Enjang & Hakim \\
\hline Dede Ucil & Uun Usman \\
Obay B & Empi \\
Asep B & \\
Ule & Asep RT \\
Waji & Rahmatullah \\
Efen & Dadan \\
Raja & Eem \\
Abuy & Haqi \\
Ujang Tarsan & Hapi \\
Ujang B & Jamil \\
Engkos & Didin \\
\hline
\end{tabular}

Sumber : (Wawancara Pendamping Program Dompet Dhuafa Ayi Rahmat 09 April 2018)

Data keanggotaan dan mitra kampung ternak al ikhwan cianjur Tabel 2. Data Keanggotaan Penerima Manfaat Kampung Ternak

\begin{tabular}{lllll}
\hline No & Nama & Jumlah Domba & Status & \multirow{2}{*}{ Lokasi } \\
\cline { 1 - 2 } 1 & Mang Ule & 7 & Mitra & \\
2 & Mang Enjang & 10 & Anggota & \\
3 & Mang Waji & 7 & Mitra & \\
4 & Bah Efen & 5 & Mitra & Hanjawar \\
5 & Dede Ucil & 5 & Anggota & \\
6 & Yunus & 2 & Sekretaris & \\
7 & Raja & 5 & Mitra & \\
8 & Asep B & 7 & Anggota & \\
9 & Mang Abuy & 5 & Mitra & Babakan- \\
10 & Ujang Baslub & 10 & Mitra & Sukamanah \\
11 & Ujang Tarsan & 10 & Mitra & Mitra \\
12 & Engkos & 5 & &
\end{tabular}

Tadbir: Jurnal Manajemen Dakwah Vol. 2 No. 2 (2017) 191-212 


\begin{tabular}{|c|c|c|c|c|}
\hline 13 & Didin & 5 & Mitra & \\
\hline 14 & Obay Suhendri & 10 & Ketua & \\
\hline 15 & Obay B & 10 & Anggota & \\
\hline 16 & Sutisna & 5 & Bendahara & \\
\hline 17 & Hakim & 5 & Anggota & \\
\hline 18 & Uun Usman & 5 & Anggota & \\
\hline 19 & Asep RT & 7 & Mitra & \\
\hline 20 & Rahmatullah & 5 & Mitra & Pasirsirem \\
\hline 21 & Empi & 5 & Anggota & \\
\hline 22 & Dadan & 5 & Mitra & \\
\hline 23 & Eem & 5 & Mitra & \\
\hline 24 & Haqi & 5 & Mitra & \\
\hline 25 & Hapi & 5 & Mitra & \\
\hline 26 & Jamil & 5 & Mitra & \\
\hline
\end{tabular}

Rahmat 09 April 2018)Sumber : (Wawancara Pendamping Program Dompet Dhuafa Ayi

Dalam struktur organisasi sedikitnya membahas mengenai beberapa hal diantaranya, pembagian tugas, distribusi otoritas dan koordinasi yang dilakukan oleh sumber daya yang ada. Adapun rinciannya adalah sebagai berikut: Pertama, Pembagian Tugas. Dalam suatu organisasi besar inginpun kecil, terdapat tugas dan fungsi bagi setiap anggotanya untuk mencapai tujuan organisasi. Adapun rincian tugas-tugas sebagai berikut: (1) Pendamping Program Dompet Dhuafa Jabar. Seorang pendamping adalah pemeran kunci di dalam pengembangan masyarakat, tugas utama seorang pendamping adalah mengembangkan kapasitas masyarakat sehingga mampu mengorganisir diri dan menentukan sendiri upayaupaya yang diperlukan dalam memperbaiki kehidupan mereka. Pendamping bekerja bersama-sama masyarakat untuk membangun kepercayaan diri mereka terhadap kemampuan dan potensi yang sebenarnya mereka miliki.

Pada dasarnya pendamping memiliki tiga peran dasar yaitu: Pertama penasehat kelompok, pendamping memberikan berbagai masukan dan pertimbangan yang diperlukan oleh kelompok dalam menghadapi masalah. Pendamping tidak memutuskan apa yang diperlu dilakukan, akan tetapi kelompoklah yang nantinya membuat keputusan. Kedua, trainer participatoris, pendamping memberikan berbagai kemampuan dasar yang diperlukan oleh kelompok seperti mengelola rapat, pembukuan, administrasi, memecahkan masalah, mengambil keputusan dan sebagainya. Ketiga, Link Person peran pendamping adalah menjadi penghubung masyarakat dengan berbagai lembaga 
yang terkait dan diperlukan bagi pengembangan kelompok.

Selain tugas dan fungsi pendamping, ada prinsip-prinsip pendampingan yang dapat di gunakan diantaranya: Pertama, Prinsip Berkelompok kelompok tumbuh dari, oleh dan untuk kepentingan masyarakat. Selain dengan anggota kelompoknya sendiri, kerja sama juga dikembangkan antar kelompok dan mitra kerja lainnya agar usaha mereka berkembang, meningkatkan pendapatan dan kesejahteraan serta mampu membentuk kelembagaan ekonomi. Kedua, Prinsip Berkelanjutan seluruh kegiatan penumbuhan dan pengembangan diorientasikan pada terciptanya sistem dan mekanisme yang mendukung pemberdayaan masyarakat secara berkelanjutan. Berbagai kegiatan yang dilakukan meruPakan kegiatan yang memiliki potensi untuk berlanjut dikemudian hari. Ketiga, Prinsip Keswadayaan masyarakat diberi motivasi dan didorong untuk berusaha atas dasar keinginan dan kemampuan mereka sendiri dan tidak selalu tergantung pada bantuan dari luar. Keempat, Prinsip Kesatuan Keluarga masyarakat tumbuh dan berkembang sebagai satu kesatuan keluarga yang utuh. Kepala keluarga beserta anggota keluarga meruPakan pemacu dan pemicu kemajuan usaha. Kelima, Prinsip Belajar Menemukan Sendirikelompok dalam masyarakat tumbuh dan berkembang atas dasar keinginan dan kemampuan mereka belajar menemukan sendiri apa yang mereka butuhkan dan apa yang mereka kembangkan termasuk upaya untuk mengubah penghidupan dan kehidupannya.

Kedua, Tugas Ketua Kelompok dalam mejalankan perannya adalah sebagai berikut : (1) Mengkoordinir para Anggota dan Mitra dalam suatu kelompok ; (2) Menggerakan individu Anggota untuk tetap selaras dengan tujuan kelompok; (3) Memberikan suatu arahan mengenai tanggung jawab setiap individu Anggota dalam kelompok; (4) Mengambil keputusan atas apa yang diperlukan dalam kelompok.

Ketiga, Sekretaris bertugas sebagai berikut: (1) Mengadministrasikan segala kegiatan yang dilakukan kelompok; (2) Mengurusi persuratan yang masuk; (3) Mengurusi persuratan keluar; (4) Melakukan pengarsipan dan pendataan Anggota kelompok dan mitra;

Keempat, Bendahara bertugas sebagai berikut: (1) Mengelola dan mengatur keuangan kelompok; (2) Mencatat pemasukan dan pengelolaan keuangan kelompok;

Kelima, Tugas dari Anggota dan Mitra secara garis besar tidak jauh berbeda, tetapi yang menjadi pembeda antara anggota dan mitra yaitu secara administrasi. Anggota adalah penerima manfaat yang terdaftar sebagai penerima manfaat oleh Dompet Dhuafa sedangkan mitra yaitu jaringan untuk memperluas kebermanfaatan di kelompok sehingga apa yang di harapkan bisa tercapai, dengan arahan serta pengawasan yang dilakukan oleh anggota kelompok kampung ternak. 
Adapun tugas- tugasnya adalah sebagai berikut: (1) Mengurusi hewan ternak untuk melakukan penggemukan; (2) Memberi Pakan untuk keseharian dan kebutuhan hewan ternak lainnya; (3) Mengikuti arahan yang diberikan dari ketua kelompok dan pendamping program.

Distribusi Otoritas yang dilakukan di Kelompok kampung Ternak Al Ikhwan ini di bagi menjadi tiga otoritas atau tiga ring ini seperti tamPak pada bagan berikut:

\section{Gambar 3.3 Distribusi Otoritas}
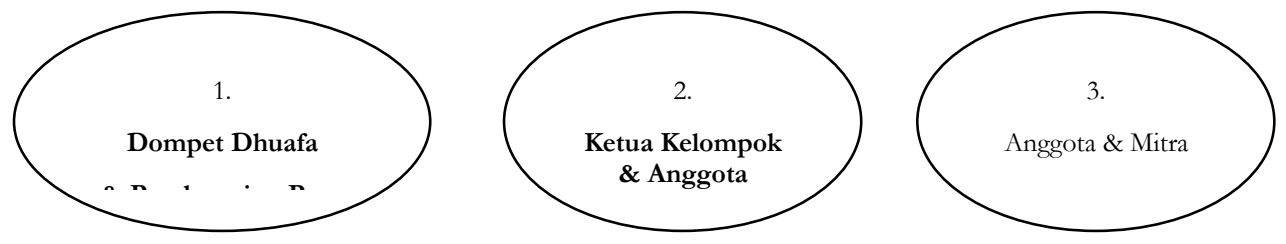

Penjelasannya:

Ring 1 ini memilik suatu kekuasaan dalam pengambilan keputusan yang sifatnya lebih kepada tataran organisasi/kelompok sehingga permasalahan yang dihadapi kelompok dan mereka sulit untuk memutuskan maka ring satu ini yang akan membantu memutuskan. Ring 2 ini memiliki suatu kekuasaan untuk mengambil keputusan permasalahan yang berhubungan dengan kelompok dan anggota kelompok, seperti kemajuan kelompok dan permasalahan seperti kematian hewan ternak. Ring 3 ini memiliki suatu kekuasaan untuk mengatur dan menyelesaikan permasalahan yang terjadi di mitra, seperti ada mitra yang tidak sejalan dengan kelompok yang tidak menjalankan tanggung jawab yang seharusnya, (Wawancara Ayi Rahmat 9 April 2018).

Kegiatan-kegiatan yang dilakukan di kelompok atau individu ini perlu pengkoordinasian agar tidak terjadinya kesalahan informasi, sehingga ketika terjadi suatu permasalah bisa di bicarakan dengan proses musyawarah. Koordinasi yang dilakukan kelompok ini ada beberapa segmen yaitu: Pertama, Koordinasi yang dilakukan oleh anggota kelompok dengan ketua kelompok mengenai permasalahan yang terjadi di kelompok. Misal, permasalahan hewan ternak dari mulai kesehatan, kematian dan kejadian yang lainnya itu di koordinasikan kepada ketua kelompok yang kemudian dilaporkan kepada pendamping program untuk tindakan selanjutnya.

Kedua, Koordinasi yang di lakukan oleh pendamping program kepada Manajer Program Dompet Dhuafa mengenai pelaporan kegiatan dan lain sebagainya. Koordinasi antara Anggota kelompok kepada ketua kelompok mengenai kegiatan dalam operasional pengurusan hewan ternak dari mulai 
kegiatan penyuntikan, kajian mingguan inginpun bulanan dan hasil- hasil yang dicapai, sertaa rencana yang akan di jalankan oleh kelompok.

Pengorganisasian merupakan kata aktif dari organisasi, kata ini berasal dari bahasa Yunani dengan akar kata organ, organon atau organum yang berarti alat, bagian, atau komponen- komponen (Manulang, 2012: 67).

Pengorganisasian berasal dari kata organism (Organisme) yang meruPakan sebuah entitas dengan bagian-bagian yang terintegrasi hingga satu dengan yang lain dalam hubungannya saling mempengaruhi (Terry, 1986: 233).

Organisasi sebagai upaya pengelompokan individu secara terstruktur yang dapat bekerja sama untuk mencapai tujuan, dengantiga unsur pendukung yakni interaksi manusia, aktivitas yang diarahkan oleh tujuan dan struktur (Setiawan, 2017: 20).

Dana zakat, infak, sodaqah, dan wakaf yang himpun oleh Dompet Dhuafa Jabar dalam proses penyaluran dana Ziswaf di organisasikan secara hati-hati sehingga dana ini dapat sampai kepada haknya dan tujuannya dapat tercapai, dengan harapan mustabik bisa menjadi muraki selanjutnya. Hal ini di tandai dengan adanya assessment terlebih dahulu sebelum di salurkan kepada para mustahik dan beberapa persyaratan dalam pengajuan yang harus dipenuhi oleh pihak yang bersangkutan sebagai tanda dokumen sebagai bukti. Persyaratan tersebut bukan bertujuan mempersulit untuk mendapatkan bantuan, tetapi ada hal yang harus diprioritaskan supaya amanah bisa di sampaikan kepada haknya.

Selain dipandang dari proses penerima manfaat, staf atau pegawai didalamnya yang mengatur dana Ziswaf dilakukan pengorganisasian dengan seperti Job Description masing-masing. Dari mulai yang bertugas mengelola keuangan, pelayanan zakat, penghimpunan sampai yang bertugas dalam penyaluran zakat. Itu semua dijalankan dengan tanggung jawab masing-masing yang telah di bebankan oleh lembaga atau.

Program-program yang dikeluarkan oleh lembaga Dompet Dhuafa pun tidak terlepas dari proses manajemen salah satunya dilakukannya pengorganisasian. Ini dilakukan ketika program di rancang sampai pelaporan atau pengkoordinasian program tersebut sebelum di luncurkan. Dalam proses perancangan di bahas tentang siapa yang bertanggungjawab di dalamnya serta tugas, targetnya apa, sasaran, fasilitas dan standar operasioanal nya seperti apa. Sehingga program tersebut bisa tersusun secara terarah dan terorganisir.

Salah satu contoh program dompet dhuafa yang melalui pengorganisasian yaitu Program Ekonomi di Kampung Ternak Al Ikhwan Cianjur.

Struktur Organisasi yang diterapkan di kelompok kampung ternak $\mathrm{Al}$ Ikhwan cianjur adalah organisasi garis, dalam model ini kekuasaan pendamping langsung kepada ketua kelompok yang kemudian ke anggota dan mitra. dapat dilihat dari strukturnya ini meruPakan organisasi/kelompok yang sederhana 
dengan ciri-ciri sebagai berikut (1) Jumlah karyawan sedikit; (2) MeruPakan organisasi yang tergolong masih kecil (3) Antar anggota dan mitra saling mengenal akrab; (4) Spesialisasi kerja; (5) masih relatif sederhana; (6) Menggunakan asas kekeluargaan.

Sistem dan struktur telah berjalan, akan tetapi masih terdapat penumpukan peran atau fungsi dalam struktural. Seperti dalam hal pengadministrasian, pengarsipan ini masih bertumpu pada satu orang. Hal ini diperlukan pemahaman dan penekanan peran masing-masing agar jelas tugasnya ini akan berdamPak pada keberlangsungan suatu kelompok atau organisasi. Secara singkat dibutuhkan pengaktifan fungsi dan peran dengan memberikan pengarahan dan pemahaman mengenai pengadministrasian.

Yang berdampak pada perintah berjalan lancar, keputusan diambil dengan cepat dan solidaritas antara karyawan dapat terbangun secara akrab.

Kegiatan yang dilakukan penerima manfaat setiap harinya, telah mengerti fungsi dan peran yang harus dijalankan karena ini di latar belakangi pengalaman dan kebiasaan dari penerima manfaat dalam pengurusan atau pemeliharaan hewan ternak, sehingga tidak terjadi tidak pahaman dalam tindakan.

Alur koordinasi yang dilakukan pada kelompok kampung ternak al ikhwan ini adalah horizontal dan vertikal. Horizontal itu dilakukan untuk hal yang sifatnya mendesak seperti oprasional kelompok daan pengembangan program sehingga dibutuhkaan untuk koordinasi, sedangkan vertikal itu dilakukan ketika kegiatan keanggotaan yang dilakukan di kelompok seperti pelatihan dan pembinaan itu dilakukan melalui musyawarah.

Dalam distribusi otoritas pun telah jelas siapa yang mengurusi dan siapa yang memutuskan suatu permasalahan dalam kelompok baik sifatnya mendesak inginpun tidak.

\section{Kompetensi Sumber Daya pada Program Kampung Ternak Al Ikhwan Cianjur}

Dalam menjalankan suatu roda organisasi/kelompok diperlukan adanya kompetensi sumber daya untuk membantu tercapainya tujuan organisasi/ kelompok. Dengan kompetensi ini kita bisa mengukur sejauh mana kemanpuan sumber daya ini bisa mencapai suatu tujuan. Dalam hal ini kompetensi sumber daya di bagi menjadi dua yaitu; kompetensi sumber daya Manusia dan komptensi

Sumber daya Nonmanusia. Untuk mengetahui kompetensi keduanya dilakukanlah suatu tahapan program untuk meminimalisir kegagalan program. Tahapan program meliputi kegiatan pra-persiapan yang pelaksanaannya membutuhkan waktu sekitar 1-2 bulan dan kegiatan persiapan dengan waktu pelaksanaan sekitar 1 bulan.

Adapun rincian nya sebagai berikut: Pertama Pra-Persiapan. pengumpulan data sekunder yang berkaitan dengan wilayah sasaran dan kelompok sasaran. 
Dengan kriteria-kriteria sasaran program sebagai berikut: Pertama, Kriteria Kelompok Sasaran dari segi pendapatan: (1) Kepala keluarga yang mempunyai penghasilan per hari kurang dari sama dengan Rp. 50.000, atau di bawah UMK untuk wilayah pedesaan (Rural); (2) Kepala keluarga yang mempunyai penghasilan per hari kurang atau sama dengan Rp. 75.000, atau dibawah UMK untuk wilayah pinggiran kota (Sub Urban) dan perkotaan (Urban); (3) Kondisi rumah (Milik sendiri/sewa/kontrak) kurang layak dan kepemilikan harta (peralatan hidup) atau lahan usaha terbatas ( $<2000$ M2). Selain itu ada penilaian dari tokoh dan masyarakat setempat bahwa yang bersangkutan termasuk kategori kurang mampu atau miskin. Kedua, Dari segi potensi usaha: (1) Ketersediaan bahan baku; (2) Kapasitas produksi; (3) Potensi pasar dan nasional ;(4) Daya serap tenaga kerja; (5) Potensi pemberdayaan untuk menciptakan usaha turunan, artinya dalam pengembangan usaha tersebut akan dimungkinkan untuk member peluang pekerjaan dan atau manfaat ekonomi bagi para mustahik lainnya; (6) Potensi pemanfaatan sumber daya lokal. Ketiga, Segi potensi SDM (1) Usia produktif minimal 18 tahun atau telah menikah dan maksimal 60 tahun; (2) Mempunyai visi untuk pengembangan usahanya; (3) Mampu bekerja (4) Tidak sedang menerima bantuan program yang sejenis dari pihak lain. Keempat, kriteria wilayah Sasaran (a) Wilayah Urban: (1) Daerah kumuh/marjinal dan padat penduduk: (2) Mempunyai potensi untuk dikembangkan sebagai sentra produksi; (3) Kemudahan dalam akses transportasi dan pemasaran (4) Tidak sedang menjalankan program yang sejenis dari pihak lain.(b) Wilayah Rular: (1) Mempunyai potensi komoditas unggulan yang konsumtif; (2) Memiliki potensi sumber daya alam dimana kelompok miskin mempunyai aksesibilitas dalam pengelolaan sumber daya alam tersebut; (3) Memiliki potensi SDM yang mendukung, baik dalam kualitas inginpun kuantitas; (4) Tidak termasuk daerah konflik atau daerah yang mempunyai potensi konflik yang tinggi.

Kedua Persiapan. Sosialisasi perencanaan program dengan berbagai pihak terkait pada tingkat lokal yaitu : (1) Dinas-dinas terkait, Pemda kabupaten, aparat Kecamatan, Kelurahan, dan lain-lainya; (2) Pembuatan MOU/kerja sama dengan pihak-pihak terkait; (3) Penyelenggaraan workshop sosialisasi yang melibatkan berbagai pihak-pihak terkait untuk melakukan review dan mendapatkan umpan balik serta komfirmasi hasil tahap indentifikasi ; (4) Rekomendasi untuk revisi perencanaan dengan konteks lokal dan berbasis partisipatif.

Melihat dari motivasi penerima manfaat mengikuti program ini adalah dilandasi atas dasar kebutuhan untuk memenuhi kebutuhan perekonomian peneriama manfaat. Program tersebut sedikit banyaknya membantu masyarakat dalam kebutuhan perekonomian dari mulai kebutuhan pendidikan dan lainlainnya.

Terkait penanaman konsep diri di setiap penerima manfaat, kelompok 
menmbangun suatu kegiatan melalui kajian rutin seminggu sekali. Yang didalamnya mengkaji mengenai semangat mentata kehidupan, keagamaan, dan lainnya dengan harapan bukan hanya cukup dalam segi ekonomi semata melainkan cukup pula pengetahuan ruhaniyahnya. Pengajian ini telah di konsep jauh-jauh hari oleh Pendamping Program beserta Dompet Dhuafa Jawa Barat

Menurut Moeheriono,2014:14 dalam setiap individu seseorang terdapat beberapa karakteristik kompetensi dasar, yang terdiri atas berikut ini:Pertama Watak (traits), yaitu yang membuat seseorang mempunyai sikap perilaku atau bagaimanakah orang tersebut merespon sesuatu dengan cara tertentu, misalnya percaya diri (self-confidence), kontrol diri (self-control), ketabahan atau daya tahan (hardiness); Kedua Motif (motive), yaitu sesuatu yang diinginkan seseorang atau secara konsisten dipikirkan dan diinginkan yang mengakibatkan suatu tindakan atau dasar dari dalam yang bersangkutan untuk melakukan suatu tindakan; Ketiga Bawaan (self-concept), yaitu sikap dan nilai-nilai yang dimiliki seseorang; Keempat Pengetahuan (knowledge), yaitu informasi yang dimiliki seseorang pada bidang tertentu dan pada area tertentu;Kelima Keterampilan atau keahlian (skill), yaitu kemampuan untuk melaksanakan tugas tertentu, baik secara fisik inginpun mental.

Tiga hal pokok dalam kompetensi SDM adalah Pertama, Pengetahuan (Knowladge), meruPakan penguasaan ilmu dan teknologi yang dimiliki seseorang, dan diperoleh melalui proses pembelajaran serta pengalaman selama kehidupannya. Indikator pengetahuan dalam hal ini adalah, pengetahuan manajemen bisnis, pengetahuan produk atau jasa, pengetahuan tentang konsumen, promosi dan strategi pemasaran.

Kedua, Keterampilan (Skill), adalah kapasitas khusus untuk memanipulasi suatu objek secara fisik. Indikator keterampilan meliputi keterampilan produksi, berkomunikasi, kerjasama dan organisasi, pengawasan, keuangan, administrasi dan akuntansi.

Ketiga, Kemampuan (Ability), adalah kapasitas seorang individu untuk mengerjakan berbagai tugas dalam suatu pekerjaan. Indikator kemampuan meliputi kemampuan mengelola bisnis, mengambil keputusan, memimpin, mengendalikan, berinovasi, situasi dan perubahan lingkungan bisnis.

Seperti yang telah dikatakan sebelumnya yaitu, dalam membangun suatu organisasi atau kelompok yang terarah ini tidak terlepas dari kompetensi sumber daya di dalamnya salah satu latar belakang pengalaman terkait. Dalam penelitian yang dilakukan di cianjur bahwa sannya pendamping yang mendampingi program kampung ternak di pilih berdasarkan kualifikasi yang memadai. pendamping merupakan lulusan S1-PAI dan D3 Pertanian dan dikatakan berkompeten dalam bidangnya.

Disamping itu anggota yang di bekali dengan pengalaman dalam pengurusan hewan walaupun tidak di barengi dengan latar belakang pendidikan 
yang memadai. Al hasil ketika di lihat dari kompetensi secara keseluruhan harus lebih ditingkatkan kembali dalam pelatihan mengenai hal pengorganisasian khususnya dalam hal administrasi untuk penguatan organisasi yang semestinya dilakukan oleh anggota kelompok.

\section{Hasil Pengorganisasian Program Kampung Ternak Al Ikwan Cianjur}

Hasil pengorganisasian kampung ternak Al Ikhwan di Cianjur terdapat struktur organisasi atau kelompok yang sederhana meliputi, pembagian tugas antara kelompok, koordinasi tugas yang akan dilaksanakan dan pengadministrasian kegiatan yang dilakukan oleh kelompok. Terdapat peningkatan kompetensi sumber daya manusia dengan metode pelatihan dan pembimbingan, adapun terdapat materi-materi yang disampaikan dalam pelatihan inginpun pembimbingan mengenai kekuatan ekonomi, potensi diri, dan kajian keislaman.

Masyarakat Cianjur khususnya Desa Cikondang memiliki mata pencaharian berupa berladang dan buruh pengrajin sapu injuk, penghasilan masyarakat Desa Cikondang hanya untuk memenuhi kebutuhan hidup pada sehari-harinya. Selain itu masyarakat Desa Cikondang memiliki tanggung jawab terhadap keluarganya untuk dapat membiayai kebutuhan sehari-hari seperti kebutuhan sekolah untuk anaknya, kesehatan, dan lain sebagainya.

Berdasarkan hasil wawancara dengan ujang selaku mitra dikelompok kampung ternak Al-Ikhwan Cianjur menyatakan bahwa:

Berdasarkan hasil peneliti yang dilakukan berupa wawancara dilapangan mengenai tanggapan adanya pembentukan kelompok kampung ternak $\mathrm{Al}$ Ikhwan yang diambil dari beberapa anggota kelompok. Dengan adanya kampung ternak, masyarakat dapat menambah penghasilannya untuk mencukupi kebutuhan sandang, pangan, dan papan. Penghasilan yang didapatkan oleh anggota ataupun mitra sebesar Rp.700.000,-/bulan, karena didapat dari penggemukan domba selama empat atau sampai enam bulan untuk masa panen.untuk penggemukan satu ekor domba di beri upah biaya sebesar Rp 350.000 dikalikan dengan banyaknya jumlah domba yang mereka urus (Wawancara 8 April 2018).

Hasil pengorganisasian program kampung ternak Al Ikhwan Cianjur ini diantaranya terdapat struktur organisasi kelompok walaupun masih bersifat sederhana dan secara oprasional telah berjalan, terdapat perkumpulan rutin yang dilaksanakan oleh kelompok dalam rangka penguatan potensi dalam diri setiap anggota kelompok baik dalam segi penguatan pengetahuan ekonomi mandiri inginpun pengetahuan agama, ini di tandai dengan jadwal kajian rutin yang dilakukan, serta lahir program- program kelompok seperti pembangunan rumah anggota kelompok. Selain itu terdapat pengadministrasian keuangan, laporan kegiatan dan laporan perkembangan program kampung ternak. 
Selain hal-hal tersebut, sebagian masyarakat Desa Cikondang harus melakukan hal seperti meminjam pada suatu instansi dengan bunga yang cukup besar dan sistem pengembalian pinjaman setiap hari untuk memenuhi kebutuhan pokok, modal usaha, dan lainnya. Hal ini menimbulkan beban bagi sebagian masyarakat Desa Cikondang yang tidak mampu untuk mengembalikan apa yang mereka pinjam sehingga harus menggadaikan apa yang mereka miliki. Kampung ternak ini dapat memberikan solusi bagi masyarakat yang ingin keluar dari keterpurukan ekonomi dengan bersama berupaya tanpa harus menggunakan cara meminjam, (Ketua Kelompok Obay 8 April 2018).

Pengorganisasian kelompok Kampung Ternak telah dirasakan oleh masyarakat khususnya penerima manfaat, karena dengan adanya program ini membantu mereka untuk memenuhi kebuthan yang sifatnya lebih penting dan mendesak, seperti biaya sekolah, biaya rumah tangga dalam jangka panjang.

Program ini juga telah melakukan pembangunan dan renovasi rumah penerima manfaat, dengan kondisi rumah yang telah tidak layak untuk di huni, dengan dibantu oleh para donator yang mengunjungi kampung ternak.

Terdapat beberapa program pada kampung ternak Al Ikhwan seperti terdapat bantuan renovasi rumah serta pembangunan rumah salah satu anggota kelompok yang tidak layak untuk ditempati. Seperti halnya diungkapkan oleh pendamping program kampung ternak bahwa anggota yang bernama Obay B berusia 50 Tahun dan mempunyai seorang anak yang masih duduk di bangku sekolah serta memiliki permasalahan yang dialami rumah tangganya yang dipicu dengan keterbatasan ekonomi, kesadaran keislaman. Melihat kondisi seperti itu kelompok sePakat untuk membantu merenovasi atau membangunkan rumah untuk Pak obay yang di bantu oleh bebrapa donator dan dana kelompok, (Wawancara pendamping program Ayi Rahmat, 09 April 2018).

Hasil lainnya yang di rasakan oleh khalayak ramai masih dalam proses upaya peningkatan seperti mengadakan pengajian rutin untuk umum mengenai pengetahuan keagamaan. harapan dari dana kelompok dapat disisihkan untuk membeli lahan untuk investasi jangka panjang untuk kelangsungan kemanfaatan, sehingga penerima manfaat tidak hanya mengandalkan program ini tetapi pengembangan program pun mereka rasakan.

Gambar 3.4 Pembangunan Rumah Salah Satu Anggota Kampung Ternak tahun 2018

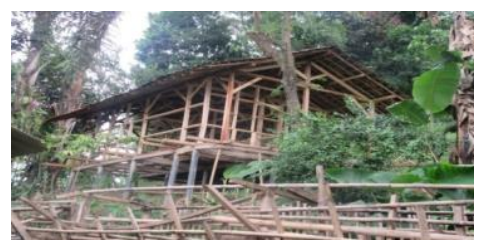


Gambar di atas merupakan proses pembangunan rumah Pak Obay dengan harapan dapat membantu semangat dalam membangun kehidupannya lagi untuk kedepannya.

Program merupakan pernyataan yang berisi kesimpulan dari beberapa harapan atau tujuan yang saling bergantung dan saling terkait, untuk mencapai suatu sasaran yang sama. Biasanya suatu program mencakup seluruh kegiatan yang berada di bawah unit administrasi yang sama, atau sasaran-sasaran yang saling bergantung dan saling melengkapi, yang semuanya harus dilaksanakan secara bersamaan atau berurutan, (Muhaimin ,2009:349).

Indikator Efisiensi, indikator ini mengukur aPakah sumber daya dan aktivitas program yang dilaksanakan untuk mencapai tujuan telah dimanfaatkan secara tepat guna (efisien), atau tidak memboroskan sumber daya yang ada dalam mencapai tujuan.

Indikator Kualitas indikator ini untuk mengukur standar kualitas dari pelayanan yang dilakukan atau disampaikan oleh pelaksana program kepada kelompok/ komunitas sasaran. Apakah pelayanan yang diberikan telah memenuhi syarat dalam hal keresponsifan, pendampingan, empati, keamanahan penyaluran dana program dan sebagainya.

Indikator dampak indikator ini melihat apakah kegiatan program yang dialakukan benar- benar memberikan suatu perubahan dimasyarakat atau penerima manfaat. Pengukuran indikator ini melalui kaji 1-2 tahun kemudian setelah program dimandirikan di komunitas saran (Tim Divisi Prog 2015: 25).

\section{PENUTUP}

Berdasarkan hasil penelitian yang dilakukan di Lembaga Amil Zakat Nasional Dompet Dhuafa Jawa Barat dengan judul "Pengorganisasian dana Ziswaf pada Program Ekonomi Masyarakat Mandiri" dapat diambil kesimpulan sebagai berikut:

Struktur Organisasi yang diterapkan di kelompok kampung ternak Al- Ikhwan Cianjur adalah organisasi garis, dalam model ini kekuasaan pendamping langsung kepada ketua kelompok yang kemudian ke anggota dan mitra. Dapat dilihat dari struktur organisasi/kelompok Kampung ternak Al-Ikhwan yang sederhana dengan ciri-ciri sebagai berikut: (1) Jumlah karyawan sedikit; (2) 
Merupakan organisasi yang tergolong masih kecil; (3) Antar anggota dan mitra saling mengenal akrab; (4) Spesialisasi kerja masih relatif sederhana; (5) Menggunakan asas kekeluargaan;

Organisasi tersebut yang berdampak pada perintah berjalan lancar, keputusan diambil dengan cepat dan solidaritas antara karyawan dapat tetap terjalin akrab.

Kompetensi Sumber Daya yang ada di Kelompok Kampung Ternak Al-Ikhwan cianjur dari mulai wilayah itu telah dilakukan observasi terlebih dahulu dari mulai ketersediaan Pakan, dan fasilitas lainnya telah mendukung, dan penerima manfaat pun yang mengajukan telah mengalami beberapa tahap wawancara dan pengalaman mengenai pemeliharaan hewan ternak sehingga secara praktis mereka berpengalaman.

Hasil Pengorganisasian di Kelompok Kampung Ternak Al-Ikhwan Cianjur adanya struktur yang jelas, peningkatan sumber daya baik melaluai pelatihan inginpun kajian, serta adanya pengadministrasian keorganisasian seperti keanggotaan, keuangan, dan kegiatan. Selain itu juga kampung ternak telah membantu penerima manfaat meningkat penghasilannya sebesar Rp. 700.000,/ Bulan. Selain itu program ini juga membantu angota untuk pembangunan rumah.

Program ini juga telah melakukan pembangunan rumah penerima manfaat, dengan kondisi rumah yang telah tidak layak untuk di huni, dengan usaha penerima manfaat mengurus domba dan di bantu dengan kelompok beserta para donator kampung ternak.

Berdasarkan hasil penelitian yang dilakukan di lembaga Amil Zakat Dompet Dhuafa Jawa Barat dengan judul "Pengorganisasian dana Ziwaf pada program ekonomi masyarakat mandiri "Studi kasus di Kampung Ternak Al Ikhwan Cianjur. Peneliti memberikan saran mengenai penelitian yang telah dilakukan mengenai pengorganisasian adalah sebagai berikut:

Pertama, Dalam lingkup kelompok khususnya di Kampung Ternak Al Ikhwan Cianjur diharapkan lebih memperkuat sistem administrasi Kelompok, dari mulai pengarsipan data-data anggota, mitra, keuangan dan lain halnya yang menyangkut dengan administrasi. supaya roda organisasi bisa berjalan dan berkembang secara tersistematis.

Kedua, Pada umumnya setiap kelompok memiliki pencatatan keuangan dan keanggotaan secara sederhana, pendamping program dapat secara bertahap melakukan program pembaharuan sehingga kelompok memiliki sistem administrasi yang standar bagi kepeluan yang lebih luas.

Ketiga, Diharapkan adanya pemahaman peran dan fungsi dalam struktural bagi setiap individu sehingga tidak bertumpu pada satu orang saja

Keempat, Pengembangan program dari mulai pemasaran diharapkan tidak hanya di serap pada program tebar hewan kurban sehingga pendanaan untuk 
kelompok pun bisa berjalan lebih lancar karena ini di latar belakangi pada dana talangan untuk anggota yang mengambilseparuh gaji/ kasbon terlebih dahulu.

\section{DAFTAR PUSTAKA}

Koentjaraningrat, (1990). Pengantar Ilmu Antropologi. Jakarta:Aksara Baru

Manulang, (2012). Dasar-Dasar Manajemen. Gadjah Mada University Press. Yogyakarta

Malthis, dkk, (2006). Human Resource Management (Manajemen Sumber Daya Manusia), Edisi Sepuluh, Terjemahan : Diana Angelica, Jakarta: Salemba Empat,

Moeheriono, (2014). Pengukuran Kinerja Berbasis Kompetensi - Competency Based Human Resources Management, Edisi Revisi Cetakan ke 2, , Jakarta: Rajawali Pers.

Nafarin, (2007). Penganggaran Perusaabaan Edisi Ketiga.Jakarta :Salemba Empat

Robins, S. P. (2009). Teori Orgaanisasi Struktur, Desain \& Aplikasi Edisi 3. Jakarta:Arcan

Soegoto, E. S. (2009). Enterpreneurship Menjadi Pembisnis Ulung. Jakarta: Elex Media Komputindo

Muhaimin, dkk (2009). Manajemen Pendidikan. Jakarta:Kencana

Silalahi, U. (2011). Asas-asas Manajemen. Bandung:PT Refika Aditama

Wibowo, (2013). Manajemen Kinerja Edisi Ke-3. Jakarta: PT Raja Grapindo Zen, M., dkk. (2005). Zakat dan Wirausaha. Jakarta: CED.

Setiawan, H. (2017). Manajemen Komunikasi Dompet Ummat dalam Pemberdayaan Ekonomi Umat Islam. Ilmu Dakwah: Academic Journal for Homiletic Studies, 11(1), 89-110. 
E. Saepudin, D. Sadiah, A. Aziz 